\title{
Accessory Reproductive Organs Dimension of Two Species of Giant African Land Snails Archachatina marginata and Achatina achatina at Three Liveweight Ranges
}

\author{
J. A. Abiona (Corresponding author) \\ Department of Animal Physiology
}

University of Agriculture, P. M. B. 2240 Abeokuta, Ogun State, Nigeria

Tel: 234-80-6726-8826 E-mail: abionajohn@yahoo.ca

$$
\text { O. A. Osinowo }
$$

Department of Animal Physiology

University of Agriculture, P. M. B. 2240 Abeokuta, Ogun State, Nigeria

Tel: 234-80-3318-7110 E-mail: exmay565@yahoo.com

D. Eruvbetine

Department of Animal Nutrition

University of Agriculture, P. M. B. 2240 Abeokuta, Ogun State, Nigeria

Tel: 234-80-3312-7433 E-mail: daisy@eruvbetine.com

$$
\text { M.O. Abioja }
$$

Department of Animal Physiology

University of Agriculture, P. M. B. 2240 Abeokuta, Ogun State, Nigeria

Tel: 234-80-3395-2155 E-mail: dimejiabioja@yahoo.com

$$
\text { O. F. Smith }
$$

Department of Animal Physiology

University of Agriculture, P. M. B. 2240 Abeokuta, Ogun State, Nigeria

Tel: 234-80-3459-2474 E-mail: smith_olusiji@yahoo.com

$$
\text { J. O. Daramola }
$$

Department of Animal Physiology

University of Agriculture, P. M. B. 2240 Abeokuta, Ogun State, Nigeria

Tel: 234-80-5109-9403 E-mail: daramolajames2003@yahoo.com

\section{A. O. Ladokun}

Department of Animal Physiology

University of Agriculture, P. M. B. 2240 Abeokuta, Ogun State, Nigeria

Tel: 234-803-211-0594

$$
\text { I. J. James }
$$

Department of Animal Physiology

University of Agriculture, P. M. B. 2240 Abeokuta, Ogun State, Nigeria

Tel: 234-806-067-2833 E-mail: james_ikej@yahoo.com 


\author{
O. S. Abe
}

Department of Animal Breeding and Genetics

University of Agriculture, P. M. B. 2240 Abeokuta, Ogun State, Nigeria

Tel: 234-805-530-0225Ｅ-mail: abeolugbenga@yahoo.com

O. M. Onagbesan

Department of Animal Physiology

University of Agriculture, P. M. B. 2240 Abeokuta, Ogun State, Nigeria

Tel: 234-703-320-4685Ｅ-mail: onagbesanok@yahoo.com

Received: April 1, $2011 \quad$ Accepted: April 15, $2011 \quad$ Online Published: December 21, 2011

doi:10.5539/jas.v4n2p179

URL: http://dx.doi.org/10.5539/jas.v4n2p179

\begin{abstract}
A comparative study of the reproductive tract of two species of Giant African Land Snails, Archachatina marginata and Achatina achatina was carried out. Three groups of snails weighing 80-100,101-150 and 151-250 g were used in a $2 \times 3$ factorial design, with 5 replicates, involving a total of 30 snails. Dimensions and weights of retractor penile muscle, vas deferens, penis, vagina, oviduct, spermotheca, common duct, albumen gland and little hermaphrodite duct were taken. Results showed that Archachatina marginata had longer, wider and heavier accessory sex organs compared to Achatina achatina except for vas deferens width, vagina length, vagina width, and vagina weight, which were otherwise. Dimensions and weights of the accessory organs increased consistently with liveweight, except for retractor penile muscle width, which had attained maximum size by a body weight of 101-150 g. It can be concluded that Archachatina marginata had better reproductive tract dimension compared to their counterpart (Achatina achatina). It is however recommended that liveweight group 151-250 $\mathrm{g}$ be considered as group of choice when considering anatomical display of reproductive parts for demonstrative purpose and testing of manipulating tools for reproductive strategies in both species.
\end{abstract}

Keywords: Dimension, Accessory reproductive organs, Giant African land snails, Liveweight groups

\title{
1. Introduction
}

Remarkable differences in the growth rate, number of eggs laid and slight differences in term of environmental tolerance raises suspicion for morphometric differences in the accessory reproductive organ of the two prominent species of giant African Land Snails (Archachatina marginata and Achatina achatina) raised in Nigeria. Although, sexual maturity is attained between 7 to 11 months in Achatina achatina and 9 to 10 months in Archachatina marginata (Amusan and Omidiji, 1998). The average number of eggs laid per clutch by Archachatina marginata was given to be 5 to 11 with lager size while Achatina achatina lays hundreds, though smaller in size (Awesu, 1980; Hodas, 1984; Ajayi et al., 1987; Amusa and Omidiji, 1998,). Since reproductive tract play vital role in hormone production (responsible for growth), germ cell production, even access for reproductive manipulation and practical demonstration for research purposes, thus, any differences in the reproductive tract dimension between the two species of the same liveweight may be a useful information on the reproductive strategy of choice which may be applied to boost production in any of two species commonly reared. Also, differences in morphometric dimension of the reproductive tract may also be a factor responsible for differences in both growth rate and number of eggs laid by the two species as caused by genetic factor (Abiona, 2005). The present study was designed to investigate the morphometric differences in the accessory reproductive organs of two species of giant African Land Snails (Archachatina marginata and Achatina achatina) commonly reared in Nigeria.

\section{Materials and Methods}

\subsection{Experimental Area}

The study was carried out at the Physiology Laboratory, College of Animal Science and Livestock Production, University of Agriculture, Abeokuta, Nigeria. The location lies within the rain forest belt of Western Nigeria, latitude $7^{0} 10^{\prime} \mathrm{N}$, longitude $3^{0} 2^{\prime} \mathrm{E}$ and altitude 76 masl. The climate is humid with a mean annual rainfall of 1,037 $\mathrm{mm}$, mean temperature of $34.7^{\circ} \mathrm{C}$ and mean relative humidity of $82 \%$ (Abioja, 2005). 


\subsection{Experimental animals and their management}

Thirty snails (15 Archachatina marginata and 15 Achatina achatina) used for this study were obtained from the Snail Unit of University of Agriculture, Abeokuta, Nigeria. The snails were fed $75 \mathrm{~g}$ of a mixture of layer's mash and dried pawpaw leaves $(1: 1, \mathrm{w} / \mathrm{w})$ per day, while water was provided ad libitum in plastic troughs. Feed and water troughs were washed daily, while the soil in each cage was changed every two weeks to maintain good sanitation. The dimension of the cage in which the animals were kept is $34 \mathrm{~cm} \times 22 \mathrm{~cm} \times 25 \mathrm{~cm}$.

\subsection{Procedure of experiment}

The snail were weighed (using sensitive scale) and grouped based on their weight as; small (80-100 g), medium (101-150 g) and large (151-250 g).

The parameters taken after dissection were weight (using weighing scale), length (tape rule) and width (venier caliper) of the following organs and tissues:

(1) Common duct

(2) Albumen gland

(3) Little hermaphrodite duct

(4) Penis

(5) Vas deferens

(6) Retractor penile muscle of the penis

(7) Vagina

(8) Oviduct

(9) Spermotheca

\subsection{Statistical analysis}

The morphometric data generated were subjected to least squares analysis of variance (SYSTAT, 1993), significant treatment means were separated using Duncan multiple range test (Gomez and Gomez, 1984). The model used for the analysis was:

$$
\mathrm{Y}_{\mathrm{ijk}}=\mu+\mathrm{A}_{\mathrm{i}}+\mathrm{B}_{\mathrm{j}}+\mathrm{AB}_{\mathrm{ij}}+\mathrm{E}_{\mathrm{ijk}}
$$

Where $Y_{i j k}=$ Trait of interest, $\mu=$ population mean, $A_{i}=$ Effect due to $i^{\text {th }}$ species, $B_{j}=$ Effect due to $j^{\text {th }}$ live weight group, $\mathrm{AB}_{\mathrm{ij}}=$ Effect due to interaction between $\mathrm{i}^{\text {th }}$ species and $\mathrm{j}^{\text {th }}$ weight group and $\mathrm{E}_{\mathrm{ijk}}=$ Residual error.

\section{Results and Discussion}

The mean values of length, width and weight of different accessory sex organ of the reproductive tracts of the two species of giant African land snails are presented in Table 1 and Figure 1-4. No significant $(p>0.05)$ difference was obtained in length, width and weight of albumen gland in the two species $(3.48 \mathrm{~cm}, 1.02 \mathrm{~cm}$, and $1.77 \mathrm{~g}$ vs $2.56 \mathrm{~cm}$, 0.78 and $1.22 \mathrm{~g}$ ). The present study showed no significant difference in length, width and weight of albumen gland for both species. The albumen gland-capsule gland complex is involved in the formation of envelopes surrounding the fertilized oocytes. The parenchymal glandular mass exhibits tubular- acinous adenomeres formed by the two cell types: albumen secretory cells and labyrinthic cells alternately arranged and joined by zonulae adherense and septate junctions (Catalan et al., 1996; Winik et al., 1998). The observation made on the albumen gland suggest that the secretory role played by the albumen gland of both species are similar, and since ova production in giant African land snails are known to be seasonal (Yoloye, 1994), then the dimension may be similar, base on their secretory activities since both species are known to lay eggs during raining season.

Similarly, retractor penile muscle lengths, width and weight were not significantly $(\mathrm{P}>0.05)$ different for both species $(2.08 \mathrm{~cm}, 0.39 \mathrm{~cm}$ and $0.04 \mathrm{~g}$ vs $2.01 \mathrm{~cm}, 0.39 \mathrm{~cm}$ and $0.02 \mathrm{~g}$, correspondingly). Little hermaphrodite duct length, penis width, vas deferens weight and vagina width followed the same trend. The common duct length, width and weight showed highly significant $(\mathrm{P}<0.001)$ difference between species. Little hermaphrodite duct width and weight were significantly $(\mathrm{P}<0.01$ and $\mathrm{P}<0.001$ respectively) affected by species. Retractor penile muscle withdraws penis after copulation while little hermaphrodite duct store spermatozoa (Abiona, 2005). Similarly, both vagina and penis are known as copulatory organ. In this study, little hermaphrodite duct length, penis width, vas deferens weight and vagina width which were found not to be significantly different in both species may be as a result of similar architecture of these organs in both snails. However, Archachatina marginata recorded higher numerical value compared to Achatina achatina with the exception of vagina width. Both 
common duct (length, width and weight) and little hermaphrodite duct (width) that were not significantly different were further proof that marginata have longer, wider and heavier accessory organs compared to Achatina.

Archachatina marginata showed significantly $(\mathrm{P}<0.01)$ higher values for oviduct length and width than Achatina achatina. This observation is a further indication of the reason while eggs oviposited by marginata are bigger and longer than those of achatina. It is a known fact that oviduct exhibits a high degree of development and structural complexity probably related to its participation in the complex reproductive processes, specifically in the transport, fertilization and provision of egg envelopes (Buckland-Nicks and Chia, 1990; Carvalho Thiengo, 1993, Schulte-Oehlmann et al., 1994) in which larger dimension of it will be required for species with larger eggs. In this study, considering the weight, it was also observed that Archachatina marginata showed significantly higher values for oviduct weight than Achatina achatina. The larger size of eggs layed coupled with volume of egg envelopes produced by marginata compared to Achatina may be the reason for this observation.

Penis length $(\mathrm{P}<0.001)$ and penis weight $(\mathrm{P}<0.05)$ were significantly affected by species.

Species effect was highly significant $(\mathrm{P}<0.001)$ for both vas deference length and width. For vaginal length and weight, Achatina achatina showed significantly $(\mathrm{P}>0.05)$ higher values than Archachatina marginata. Spermotheca length, width and weight were also significantly different $(\mathrm{P}<0.05)$ for species.

The differences in penis and Vagina (length and weight) may be one of the reasons why the two species do not interbreed with each other. The findings of this study are in line with the report of Ayodele and Ashimolowo (1999), which stated that vagina of Archachatina marginata is tubular and short while that of Achatina achatina is tubular and long. Also, shell architecture of both species which is spine-like and long in Achatina while that of marginata is robust may be another reason for the dimension seen since organs contained in the shell need to occupy the space provided (Abiona, 2007). Vas deferens plays a prominent role in spermatozoa transport while spermotheca is known for spermatozoa storage. Differences between the two species in the values recorded for vas deferens (Length and width) and spermotheca (Length, width and weight) could also be a factor militating against the two species interbreeding with each other. In all, dimension of the reproductive organs increases with the liveweight except for albumen gland. This observation is in line with the report of Idokogi and Osinowo (1998) who reported positive significant correlations between reproductive tracts and liveweight in Archachatina marginata. Also, divergence in value for albumen gland may be as a result of the role played by individual snails since alternation of reproductive activity is allowed in hermaphrodite, those performing female role are bound to have larger dimension than those with male role (Koene and Ter Maat, 2005).

The results of length, width and weight of different accessory sex organs of the reproductive tracts of the three liveweight groups (80-100 g, 101-150 g and 151-250 g) of giant African land snails are presented in Table 2. Liveweight effect was not significant $(\mathrm{P}>0.05)$ for albumen gland length, width and weight $(2.69 \mathrm{~cm}, 0.76 \mathrm{~cm}$, and $1.09 \mathrm{~g}$ vs $2.80 \mathrm{~cm}, 0.94 \mathrm{~cm}$ and $1.06 \mathrm{~g}$ vs $3.55 \mathrm{~cm}, 1.00 \mathrm{~cm}$ and $2.36 \mathrm{~g})$. This observation may be an indication of different stages of reproductive activity of the animal which is the key factor in determining the dimensions of this organ. Similarly, retractor penile muscle lengths and weight $(2.23 \mathrm{~cm}$ and $0.03 \mathrm{~g}$ vs $1.73 \mathrm{~cm}$ and $0.03 \mathrm{~g}$ vs 2.18 and $0.03)$, little hermaphrodite duct width and weight $(0.23 \mathrm{~cm}$ and $0.03 \mathrm{~g} \mathrm{vs} 0.25 \mathrm{~cm}$ and $0.03 \mathrm{~g}$ vs $0.27 \mathrm{~cm}$ and $0.05 \mathrm{~g})$ and oviduct width and weight $(0.42 \mathrm{~cm}$ and $0.06 \mathrm{~g}$ vs $0.54 \mathrm{~cm}$ and $0.06 \mathrm{~g}$ vs $0.45 \mathrm{~cm}$ and $0.01 \mathrm{~g})$ were not significantly $(\mathrm{P}>0.05)$ different considering the three liveweight groups. So also, common duct width and spermotheca width followed similar trend. This observation further substantiates the fact that the three liveweight groups used in this study were capable of performing reproductive role, although efficiency of reproduction may differ from one liveweight to another especially in term of sperm production in both species (Abiona, 2007).

There were significant $(\mathrm{P}<0.001$ and $\mathrm{P}<0.05)$ differences in common duct length and weight respectively for the three liveweight groups. The little hermaphrodite duct length for $151-250 \mathrm{~g}$ group was significantly $(\mathrm{P}<0.001)$ longer than the other two liveweight groups. Oviduct length of 151-250 g group were significantly $(\mathrm{P}<0.05)$ longer than others. Various differences seen in these organs may be attributed to frequency of use which may also be correlated to their ages and possibly their liveweight as well (Idokogi and Osinowo, 1998).

For the length, width and weight of penis respectively, the 151-250 g group was significantly $(\mathrm{P}<0.05 ; \mathrm{P}<0.01$; $\mathrm{P}<0.001)$ longer, wider and heavier than 80-100 g group, while 101-150 g group was not significantly different from 80-100 g group. This observation is also a confirmation that frequency of use of this organ which are invariably higher in higher liveweight groups may be the adduced reason for the dimension recorded. Also, Retractor penile muscle width showed a highly significant difference $(\mathrm{P}<0.001)$ among the liveweight group with the 101-150 g group showing the highest value and the 80-100 g group the least. This observation is a revelation of the reproductive agility of this group compared to other group as confirmed by their ability to produced higher 
volume of spermatozoa (Abiona, 2007). Similarly, there were significant differences $(\mathrm{P}>0.01, \mathrm{P}>0.01$ and $\mathrm{P}<0.05)$ in vas deferens length, width and weight among the three liveweight group.

Vagina length $(\mathrm{P}<0.05)$, width $(\mathrm{P}<0.01)$ and weight $(\mathrm{P}<0.001)$ were significantly affected by liveweight. The 151-250 g group showed higher values for the three parameters than 80-100 g group. It is not surprising to see such an increase in values since liveweight could be related to the age of the animal, and as such their reproductive activities are also expected to increase which can also affect the values of these organs as reported. The liveweight group effect was significant $(\mathrm{P}<0.05)$ for spermotheca length and weight. This is expected since spermotheca stores spermatozoa received from another snail during copulation. The volume stored is expected to increase with increase in liveweight which will automatically increase the dimension and weight of this organ.

\section{Conclusion}

In conclusion, Archachatina marginata had longer, wider and heavier accessory sex organs compared to Achatina achatina for most of the organs measured using three different liveweight groups. In both species livewight group $101-150 \mathrm{~g}$ is the most active in term of production given the wider dimension of the retractor muscle width, which is an organ responsible for penis withdrawal after copulation. Hence a pointer to their mating pattern, which suggest that mating activity is higher in this liveweight group compared to other liveweight. It is therefore recommended that for experiment on reproduction liveweight group 101-150 $\mathrm{g}$ would be of good choice while that of 151-250 would be good samples for anatomical display for genital tract manipulation or anatomical display for vivid clarifications of different parts of the reproductive organs of giant African land snails (Archachatina marginata and Achatina achatina).

\section{References}

Abiona, J. A. (2005). Comparative study of the accessory reproductive organs of two species of giant African land snail (Archachatina marginata and Achatina achatina) M. Agric. Dissertation. Dept. of Animal Breeding and Genetics, University of Agriculture, Abeokuta, Nigeria.

Abioja, M. O. (2005). Physiological and haematological responses of West African Dwarf and Red Sokoto goats to water restriction in humid tropical condition of South-Western Nigeria. M. Agric. Dissertation, Department of Animal Breeding and Genetics, University of Agriculture, Abeokuta, Ogun, Nigeria. Pp. 78.

Ajayi S. S., Tewe, O. O., Moriaty, C. \& Awesu, M. O. (1987). Observations on the biology and nutritive value of African giant snail (Archachatina marginata). East Afri. Wildlife J., 16: 85- 95.

Amusan, J. A. \& Omidiji, M. O. (1998). Edible land snails. A technical guide to snail farming in the tropics. Verity Printers Ibadan, Pp. 60.

Awesu, M.O. (1980). The biology and management of the giant African land snail, Archachatina marginata (swainson). Unpublished M. Phil. Dissertation, University of Ibadan, Pp. 198.

Ayodele, I.A. \& Asimolowo, A. A. (1999). Essentials of snail farming. Agape Prints U.I. Ibadan, Pp. 51.

Buckland-Nicks, J. \& Chia, F.S. (1990). Egg capsule formation and hatching in marine snail Littorina sitkana. Phil Trans R Soc Lond B, 326: 159-176. http://dx.doi.org/10.1098/rstb.1990.0001

Carvalho Thiengo S. (1993). On Pomacea canaliculata . Mem Inst Oswaldo Cruz, 88 (1): 67-71.

Hodasi J. K. M. (1984). World Animal Review, no. 52, Pp. 24-48.

Koene, J. M. \& Ter Maat, A. (2005). Sex role alternation in the simultaneously hermaphroditic pond snail Lymnaea stagnalis is determined by the availability of seminal fluid. Animal Behaviour, 69 (4): 845-850. http://dx.doi.org/10.1016/j.anbehav.2004.07.012

Schulte-Oehlmann U., Fioroni, P., Oehlmann, J. \& Stroben, E. (1994). The genital system of Marisa cornuarietis (Gastropoda, Ampullariidae). A morphological and histological analysis. Zool Beitr N F, 36 (1): 59-81.

SYSTAT. (1993). Systat Computer Package, version 5.02 Systat, Inc. 1800 Sherman Ave., Evanston, IL USA.

Yoloye, V. L. (1994). Basic invertebrate Zoology, (3rd ed) Pp. 139 - 145. 
Table 1. Species differences in dimension of the accessory sex organs of reproductive tracts of giant African land snails (A. marginata and A. achatina)

\begin{tabular}{|c|c|c|c|}
\hline & \multicolumn{2}{|c|}{ Species } & \multirow[b]{2}{*}{$\pm \mathbf{S E}$} \\
\hline & A. $\overline{\text { marginata }}$ & A. achatina & \\
\hline \multicolumn{4}{|l|}{ Parameter } \\
\hline Albumen gland length $(\mathrm{cm})$ & 3.48 & 2.56 & 0.36 \\
\hline Albumen gland width (cm) & 1.02 & 0.78 & 0.10 \\
\hline Albumen gland weight (g) & 1.77 & 1.22 & 0.37 \\
\hline Common duct length $(\mathrm{cm})$ & $5.30^{\mathrm{a}}$ & $3.58^{\mathrm{b}}$ & 0.20 \\
\hline Common duct width (cm) & $0.80^{\mathrm{a}}$ & $0.63^{\mathrm{b}}$ & 0.03 \\
\hline Common duct weight $(\mathrm{g})$ & $1.98^{\mathrm{a}}$ & $0.62^{\mathrm{b}}$ & 0.15 \\
\hline Little hermaphrodite duct length $(\mathrm{cm})$ & 3.07 & 2.61 & 0.16 \\
\hline Little hermaphrodite duct width $(\mathrm{cm})$ & $0.28^{\mathrm{a}}$ & $0.22^{\mathrm{b}}$ & 0.01 \\
\hline Little hermaphrodite duct weight (g) & $0.07^{\mathrm{a}}$ & $0.01^{\mathrm{b}}$ & 0.01 \\
\hline Oviduct length $(\mathrm{cm})$ & $1.28^{\mathrm{a}}$ & $0.83^{\mathrm{b}}$ & 0.10 \\
\hline Oviduct width (cm) & $0.60^{\mathrm{a}}$ & $0.34^{\mathrm{b}}$ & 0.06 \\
\hline Oviduct weight (g) & $0.13^{\mathrm{a}}$ & $0.01^{\mathrm{b}}$ & 0.01 \\
\hline Penis length $(\mathrm{cm})$ & $3.64^{\mathrm{a}}$ & $2.34^{\mathrm{b}}$ & 0.13 \\
\hline Penis width (cm) & 0.73 & 0.69 & 0.03 \\
\hline Penis weight $(\mathrm{g})$ & $0.82^{\mathrm{a}}$ & $0.60^{\mathrm{b}}$ & 0.06 \\
\hline Retractor penile muscle length $(\mathrm{cm})$ & 2.08 & 2.01 & 0.12 \\
\hline Retractor penile muscle width (cm) & 0.39 & 0.39 & 0.01 \\
\hline Retractor penile muscle weight (g) & 0.04 & 0.02 & 0.01 \\
\hline Vas deferens length $(\mathrm{cm})$ & $8.81^{\mathrm{a}}$ & $5.33^{\mathrm{b}}$ & 0.32 \\
\hline Vas deferens width $(\mathrm{cm})$ & $0.20^{\mathrm{b}}$ & $0.24^{\mathrm{a}}$ & 0.01 \\
\hline Vas deferens weight $(\mathrm{g})$ & 0.11 & 0.10 & 0.01 \\
\hline Vagina length $(\mathrm{cm})$ & $1.26^{\mathrm{b}}$ & $1.59^{\mathrm{a}}$ & 0.10 \\
\hline Vagina width $(\mathrm{cm})$ & 1.02 & 1.03 & 0.07 \\
\hline Vagina weight $(\mathrm{g})$ & $0.46^{\mathrm{b}}$ & $0.67^{\mathrm{a}}$ & 0.06 \\
\hline Spermotheca length $(\mathrm{cm})$ & $2.45^{\mathrm{a}}$ & $1.63^{\mathrm{b}}$ & 0.22 \\
\hline Spermotheca width $(\mathrm{cm})$ & $0.47^{\mathrm{a}}$ & $0.37^{\mathrm{b}}$ & 0.03 \\
\hline Spermotheca weight (g) & $0.13^{\mathrm{a}}$ & $0.03^{\mathrm{b}}$ & 0.02 \\
\hline
\end{tabular}

a,b, Means in the same row within the same sub-class with different superscripts differ significantly $(\mathrm{P}<0.05)$ 
Table 2. Differences in Dimension of the accessory sex organs of the reproductive tracts of $A$.marginata and $A$. achatina at three liveweight ranges

\begin{tabular}{|c|c|c|c|c|}
\hline & \multicolumn{4}{|c|}{ Weight } \\
\hline & 80-100 & 101-150 & $151-250$ & $\pm \mathbf{S E}$ \\
\hline Parameter & & & & \\
\hline Albumen gland length $(\mathrm{cm})$ & 2.69 & 2.80 & 3.55 & 0.44 \\
\hline Albumen gland width (cm) & 0.76 & 0.94 & 1.00 & 0.12 \\
\hline Albumen gland weight (g) & 1.06 & 1.06 & 2.36 & 0.45 \\
\hline Common duct length $(\mathrm{cm})$ & $3.90^{\mathrm{c}}$ & $4.31^{\mathrm{b}}$ & $5.11^{\mathrm{a}}$ & 0.25 \\
\hline Common duct width (cm) & 0.68 & 0.76 & 0.83 & 0.04 \\
\hline Common duct weight (g) & $0.85^{\mathrm{b}}$ & $1.37^{\mathrm{ab}}$ & $1.68^{\mathrm{a}}$ & 0.18 \\
\hline Little hermaphrodite duct length $(\mathrm{cm})$ & $2.37^{\mathrm{b}}$ & $2.56^{\mathrm{b}}$ & $3.60^{\mathrm{a}}$ & 0.19 \\
\hline Little hermaphrodite duct width $(\mathrm{cm})$ & 0.23 & 0.25 & 0.27 & 0.02 \\
\hline Little hermaphrodite duct weight (g) & 0.03 & 0.03 & 0.05 & 0.02 \\
\hline Oviduct length $(\mathrm{cm})$ & $0.83^{\mathrm{b}}$ & $0.97^{\mathrm{b}}$ & $1.36^{\mathrm{a}}$ & 0.12 \\
\hline Oviduct width (cm) & 0.42 & 0.54 & 0.45 & 0.07 \\
\hline Oviduct weight (g) & 0.06 & 0.06 & 0.10 & 0.01 \\
\hline Penis length $(\mathrm{cm})$ & $2.72^{\mathrm{b}}$ & $2.93^{\mathrm{ab}}$ & $3.32^{\mathrm{a}}$ & 0.16 \\
\hline Penis width $(\mathrm{cm})$ & $0.60^{\mathrm{b}}$ & $0.70^{\mathrm{ab}}$ & $0.82^{\mathrm{a}}$ & 0.04 \\
\hline Penis weight $(\mathrm{cm})$ & $0.48^{\mathrm{b}}$ & $0.69^{\mathrm{ab}}$ & $0.97^{\mathrm{a}}$ & 0.07 \\
\hline Retractor penile muscle length $(\mathrm{cm})$ & 2.23 & 1.73 & 2.18 & 0.15 \\
\hline Retractor penile muscle width $(\mathrm{cm})$ & $0.33^{\mathrm{c}}$ & $0.45^{\mathrm{a}}$ & $0.42^{\mathrm{b}}$ & 0.02 \\
\hline Retractor penile muscle weight (g) & 0.03 & 0.03 & 0.03 & 0.01 \\
\hline Vas deferens length $(\mathrm{cm})$ & $6.17^{\mathrm{b}}$ & $6.64^{\mathrm{b}}$ & $8.39^{\mathrm{a}}$ & 0.39 \\
\hline Vas deferens width $(\mathrm{cm})$ & $0.21^{\mathrm{b}}$ & $0.21^{\mathrm{b}}$ & $0.25^{\mathrm{a}}$ & 0.01 \\
\hline Vas deferens weight (g) & $0.08^{\mathrm{b}}$ & $0.09^{\mathrm{ab}}$ & $0.14^{\mathrm{a}}$ & 0.02 \\
\hline Vagina length $(\mathrm{cm})$ & $1.25^{\mathrm{b}}$ & $1.33^{\mathrm{b}}$ & $1.69^{\mathrm{a}}$ & 0.12 \\
\hline Vagina width $(\mathrm{cm})$ & $0.83^{\mathrm{b}}$ & $0.98^{\mathrm{ab}}$ & $1.27^{\mathrm{a}}$ & 0.08 \\
\hline Vagina weight (g) & $0.36^{\mathrm{b}}$ & $0.50^{\mathrm{b}}$ & $0.83^{\mathrm{a}}$ & 0.07 \\
\hline Spermotheca length $(\mathrm{cm})$ & $1.46^{\mathrm{b}}$ & $1.96^{\mathrm{ab}}$ & $2.69^{\mathrm{a}}$ & 0.27 \\
\hline Spermotheca width (cm) & 0.37 & 0.42 & 0.48 & 0.03 \\
\hline Spermotheca weight (g) & $0.02^{\mathrm{b}}$ & $0.10^{\mathrm{a}}$ & $0.11^{\mathrm{a}}$ & 0.03 \\
\hline
\end{tabular}

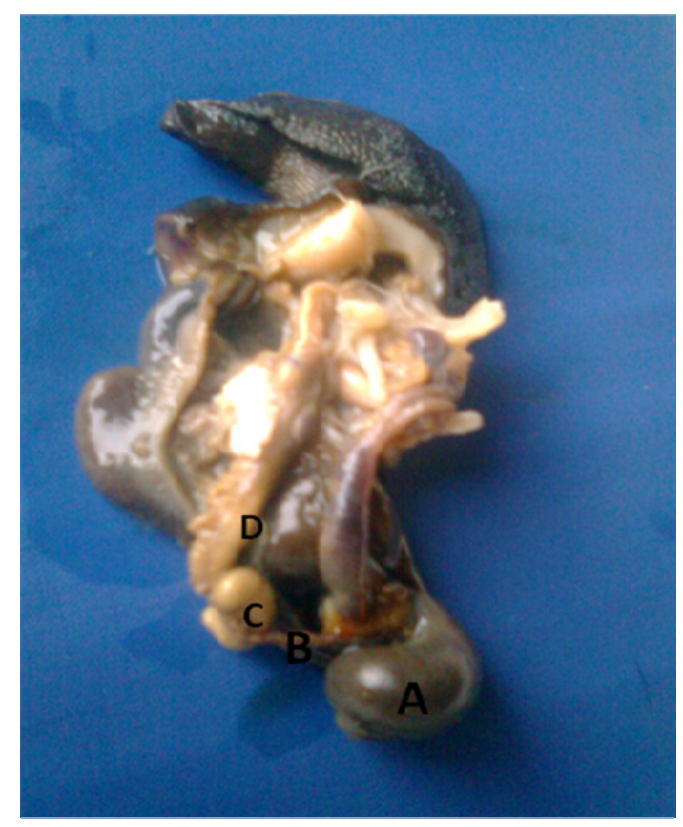

Figure 1. Ovo-testis (A), Little hermaphrodite duct (B), Albumin gland (C) and common hermaphrodite duct (D) 


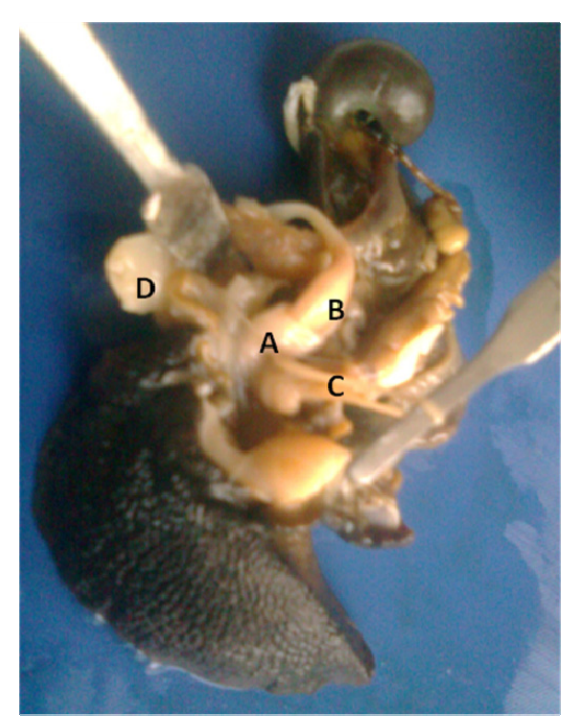

Figure 2. Penile sheath (A), Penis (B), vas deferens (C) and Retractor Penile Muscle (D)

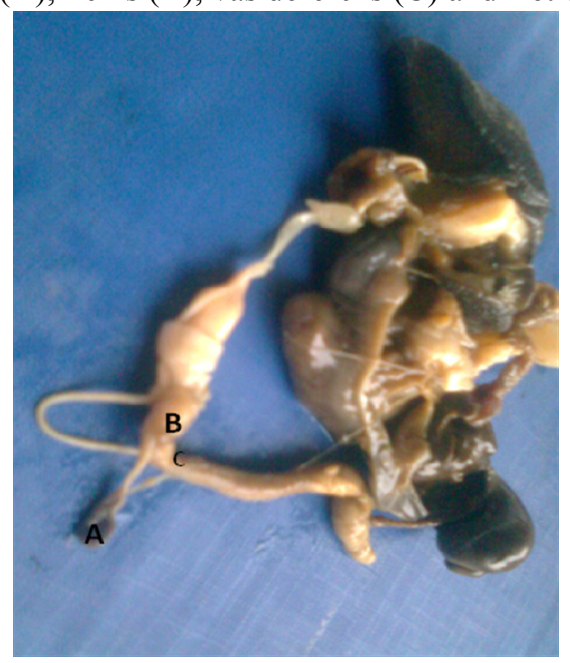

Figure 3. Spermotheca (A), Vagina (B) and Oviduct (C)

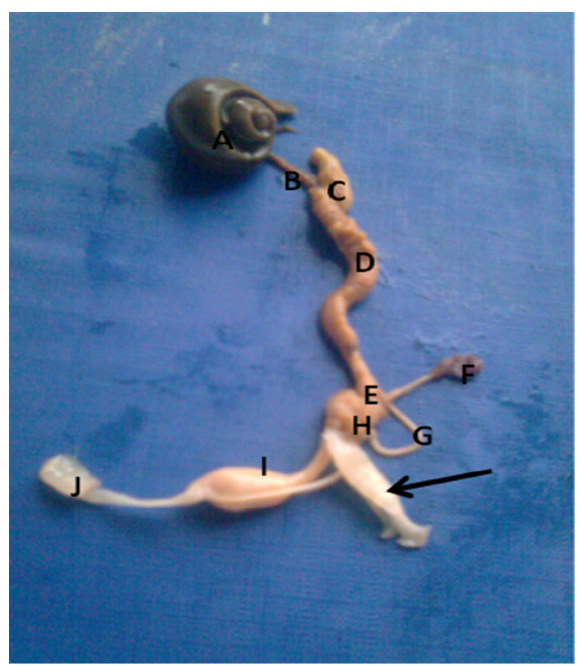

Figure 4. Complete reproductive tract of giant African land snails: Ovo-testis (A), little hermaphrodite duct (B), Albumin gland (C), Common hermaphrodite duct (D), Oviduct (E), spermotheca (F), vas deferens (G), Vagina $(\mathrm{H})$, penis $(\mathrm{I})$, Retractor penile muscle $(\mathrm{J})$ and arrow showing removed penile sheath 